\title{
Multi element (Mg, Sr, Na and K) to calcium ratio calibration of benthic foraminifera Amphistegina lessonii using controlled growth experiments.
}

\author{
LAURA PACHO SAMPEDRO ${ }^{1}$, LENNART J DE \\ NOOIJER $^{1}$, WIM BOER ${ }^{1}$ AND GERT-JAN REICHART ${ }^{1,2}$ \\ ${ }^{1}$ NIOZ-Royal Netherlands Institute for Sea Research \\ ${ }^{2}$ Utrecht University \\ Presenting Author: laura.pacho.sampedro@nioz.nl
}

The fossil shells of foraminifera are popular agents to reconstruct past climate changes. The incorporation of elements into these shells depends on various environmental conditions. The effect of these parameters (e.g. temperature, salinity, $\mathrm{pH}$ ) vary on partitioning of elements in foraminifera and are often influenced by multiple parameters. Hence combining different elemental/Ca ratios in foraminifera can be used to reconstruct different parameters simultaneously and also to improve reconstructions. For the conservative elements, such as $\mathrm{Mg}^{2+}$, $\mathrm{Sr}^{2+}, \mathrm{K}^{+}, \mathrm{Na}^{+}, \mathrm{B}(\mathrm{OH})_{3} / \mathrm{B}(\mathrm{OH})_{4}^{-}, \mathrm{SO}_{4}{ }^{2-}$, all of them with a mean oceanic residence time higher than $9 \mathrm{Myr}$, their incorporation is primarily affected by the physico-chemical conditions. The aim of the experiments is to isolate parameters of the carbonate system, salinity and temperature. We incubated specimens of the benthic foraminifera Amphistegina lessonii under a range of temperatures $\left(18-28^{\circ} \mathrm{C}\right)$. From newly formed chambers, $\mathrm{Sr} / \mathrm{Ca}$, $\mathrm{Mg} / \mathrm{Ca}, \mathrm{B} / \mathrm{Ca}, \mathrm{Na} / \mathrm{Ca}, \mathrm{S} / \mathrm{Ca}$ and $\mathrm{K} / \mathrm{Ca}$ were determined using sector field inductively coupled plasma mass spectrometry (SFICP-MS). First results suggest a positive correlation of $\mathrm{Sr} / \mathrm{Ca}$, $\mathrm{Mg} / \mathrm{Ca}$ with temperature, and $\mathrm{K} / \mathrm{Ca}$ shows an inverse correlation with temperature. This suggest these ratios are a potential proxy for temperature, while there is no effect of temperature on $\mathrm{Na} / \mathrm{Ca}$. In a second set of experiments, the impact of inorganic carbon parameters will be tested on incorporation of the same elements, forming the basis for a multi-element to multiparameter approach. 